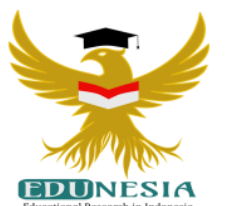

\title{
The Effect of CIRC (Cooperative, Integrated, Reading, and Composition) Method on Students Achievement in Reading Recount Text
}

\author{
Mutia Nasution \\ Department of English Education, STKIP Padang Lawas, Indonesia \\ Corresponding Email: mutianasution238@gmail.com, Phone Number:0852 xxxx xxxx
}

\author{
Article History: \\ Received: Jan 20, 2022 \\ Revised: Jan 31, 2022 \\ Accepted: Feb 06, 2022 \\ Online First: Feb 12, 2022
}

\section{Keywords:}

CIRC Method,

Reading,

Recount Text.

Kata Kunci:

Metode CIRC,

Membaca,

Teks Recount.

\begin{abstract}
This research aim is to know if there is a significant effect CIRC (Cooperative, Integrated, Reading, and Composition) Method of the tenthgrade students of SMA Negeri 1 Padangsidimpuan. The population is the tenth-grade students of SMA Negeri 1 Padangsidimpuan, which is consist of 250 students. Then, the sample is taken from the population by cluster random sampling technique and the total sample is 61 students. After calculating the data, it is found that the mean score of students reading recount text before taught by CIRC (Cooperative, Integrated, Reading, and Composition) method is 70; it is categorized as "enough". While the mean score of students reading invitation letters after being taught by CIRC (Cooperative, Integrated, Reading, and Composition) method is 90, it is categorized as "good". After finding the score of ttest and $t_{\text {table, }}$ both of the scores are compared. It is found that the $t_{\text {test }}$ is higher than $t_{\text {table }}\left(t_{\text {test }}>t_{\text {table }}=\right.$ $2,97>1,98)$ It means there is a significant effect of the CIRC (Cooperative, Integrated, Reading, and Composition) method on reading recount text of the tenth-grade students of SMA Negeri 1 Padangsidimpuan. So, the hypothesis in this research can be accepted.
\end{abstract}

Abstrak: Penelitian ini bertujuan untuk mengetahui apakah ada pengaruh yang signifikan antara metode pembelajaran CIRC (Cooperative, Integrated, Reading, and Composition) terhadap hasil belajar siswa dalam membaca teks recount pada siswa kelas X SMA Negeri 1 Padangsidimpuan. Populasi dalam penelitian ini adalah siswa kelas $X$ SMA Negeri 1 Padangsidimpuan yang berjumlah 250 siswa. Kemudian sampel diambil dari populasi dengan tekhnik cluster random sampling dan jumlah sampel sebanyak 61 siswa. Setelah dilakukan perhitungan data didapatkan bahwa rata-rata nilai siswa dalam membaca teks recount sebelum diajar dengan metode CIRC (Cooperative, Integrated, Reading, and Composition) adalah 70; dikategorikan "cukup". Sedangkan nilai rata-rata siswa membaca teks recount setelah diajar dengan metode pembelajaran CIRC (Cooperative, Integrated, Reading, and Composition) adalah 90, termasuk kategori "baik". Setelah didapatkan skor ttest dan ttabel kedua skor tersebut dibandingkan. Diketahui bahwa thitung lebih besar dari ttabel $t_{\text {table }}$ $\left(t_{\text {test }}>t_{\text {table }}=2,97>1,98\right)$ Artinya ada pengaruh signifikan antara metode pembelajaran CIRC (Cooperative, Integrated, Reading, and Composition) terhadap kemampuan membaca teks recount pada siswa kelas X SMA Negeri 1 Padangsidimpuan. Sehingga dugaan jawaban dalam penelitian ini dapat diterima. 


\section{A. Introduction}

English is used as the medium of communication. Communication or information is found usually from four skills, they are listening, speaking, reading, and writing. English is also to be one of many important subjects in school. It means that English is very important to be studied by students. It is learned from primary school until university (Kendal, 2015).

There are four basic skills in English teaching, they are listening, speaking, reading, and writing. As it is known, reading is not easy. Reading is a part of language skills in English that must be taught maximally by the teacher to the students. Reading becomes of language competence that must be mastered by students because as we know that knowledge is getting by reading activity. The information and knowledge in the books can be get through reading activities. So that reading becomes an important need for many students, especially in Senior high school in comprehending text (Souzanzan \& Zamaniyan, 2014).

Iskandarwassid \& Dadang Sunendar (2013) describe reading as an event to get the meaning of what is written in the text. For this purpose, besides the need to master the language used, the reader should also enable a variety of mental processes in the system of cognition. It means that reading is a mental process to get the meaning of the text itself. Inline Ridwanuddin (2015) suggests eight reading goals. As these goals are: (1) read relieve anxiety and anxiety; (2) when it is busy reading, someone shut out in ignorance; (3) the habit of reading makes people too busy to get in touch with people lazy and do not want to work; (4) by frequent reading, a person can develop flexibility and fluency in speaking the word; (5) read helps develop ideas and clear thinking; (6) reading increases one's knowledge and improve memory and comprehension; (7) by frequent reading, one can benefit from the experience of others, such as copying wisdom of the wise, and the intelligence of scholars; (8) by frequent reading, one can develop the ability both to receive and respond to the science and to learn discipline and application in life. It means there are eight aims of reading. Reading helps people improve their memory, comprehension, and ideas.

Yaumi (2013) said that the levels of the revised Bloom Anderson that knowing, understanding, applying, analyzing, evaluating, and creating. The ability of reading comprehension question in this research is the ability to understand the text as a whole. The ability of the invention is shown from the main idea, understand the meaning either express or implied up to deduce the content of reading. It means that there are six main points of Bloom Anderson to comprehend reading.

Reading text has many kinds in the form of descriptive, narrative, recount, news item, report, procedure, and functional text. In Senior High School students learn various reading texts. One of them is functional texts or precisely short functional texts (Ting et al, 2013).

Aryani, Samadhy, Sismulyasih, (2012) states that in 2009, Indonesia had participated in the Progress in International Reading Literacy Study (PIRLS) is an international study in the field of reading in children throughout the world aimed to obtain information about the ability of Indonesian students in the field of literacy in reading than students in other 
countries. The results of the study showed that the average Indonesian children are at fourth from bottom of the 45 countries in the world. It means that children and also students have a low interest in reading.

Besides that research, the writer found that many students are difficulty in understanding reading recount text. It is proved from their difficulties in answering questions. It can be seen from the average score is 70 . This score is still low and unsatisfactory because their Standard of minimum value (KKM) is 75 and when the researcher did observation in SMA Negeri 1 Padangsidimpuan in the last February until April. The researcher often asked the students about how to understand reading recount text but they couldn't answer it well even though their teacher had explained about it before and when their teacher explained to them, they were not interested to listen to what their teacher explained. That's why they have not understood it until now. It was alsoproved by the result of the pre-test which was gotten from the tenth-grade students in SMA Negeri 1 Padangsidimpuan 2019/2020 academic year.

To handle the problems, the teacher should be able to choose a suitable method for teaching English. If the method of teaching and learning process is based on necessity, the result of learning would be better. According to Yigit, (2015) Teachers should have a better understanding of teaching and learning to lead the learner to organize reviews their knowledge by using different methods and techniques. It means teachers should have a good understanding of teaching methods to lead their learners. While Kamisah, Wahidin, and Subhan (2013) stated that teacher pedagogical content knowledge is still low. The teacher as an instructor requires the right steps in the delivery of subjects.

Moreover, Kamisah (2013) said that the effectiveness of teaching depends on the extent to which teachers can achieve their teaching objectives to help students to learn what is being taught. At this point, effective pedagogical strategies could increase awareness of the importance of learner center. It means teachers should know their teaching objectives to help their students.

In this case, the writer is interested to choose CIRC (Cooperative, Integrated, Reading, and Composition) Method, this method is suitable for reading which focuses on activating prior. A study has suggested that cooperative learning helps in improving students' comprehension (Hafizah et al., 2010).

Maruf \& Anjely (2020) states that the CIRC method is instrumental in promoting comprehension. Some experimental studies revealed that the implementation of the CIRC method significantly enhanced students' reading comprehension. While Agustina (2015) expressed his opinion that the method of the CIRC has been selected as one of the good teaching methods for a variety of reasons,1) CIRC involves the ability to develop oral language, reading, and writing as a whole in various phases are ordered; (2) CIRC developing critical thinking skills and develop social skills of students; (3) develop a sense of appreciation and confidence; (4) help students to appreciate themselves and proficient in the national language; (5) providing a learning environment that enables the learning of different materials or the materials studied over a wide range. In addition, the CIRC method aims to 
develop the participants' ability to understand the content of reading at the same time fostering the ability to write reproduction on the reading material they read. Based on the explanation above, CIRC is suitable to improve student's ability in reading recount text.

\section{B. Method}

We need a method to get the data and information of the research. Siregar (2014) said that The use of appropriate research methods to avoid speculative problem solving and increase the objectivity in exploring knowledge. It means the use of the appropriate methodology of the research to avoid the speculative problem and to increase the objectivity to get knowledge.

The writer conducted this research at SMA Negeri 1 Padangsidimpuan. The teaching-learning process at this school is active. The process of this research for three months. In this learning model, the problem is not given by the teacher but the students raise their problem, the teacher only gives the situation and the students formulate the problem based on thatsituation (Suarsana et al, 2019).

Sugiyono (2013) says, "Method of the research is a scientific way to get the data with definite aims and used". It means that the Method of the research is an important way to get the data. According to Sugiyono (2013), the research is designed as follows:

Table 1. The Research Design

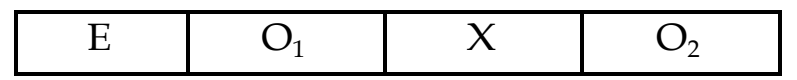

The Pattern shows:

$\mathrm{E}=$ Experimental Method

$\mathrm{O}_{1} \quad=$ Pre-test Experimental Group

$\mathrm{O}_{2} \quad=$ Post-test Experimental Group

$\mathrm{X}=$ Represent the Experimental Group Treatment

The writer chooses tenth-grade of SMA Negeri 1 Padangsidimpuanas the population of this research. They are consists of 6 classes. They are $\mathrm{X}_{1}, \mathrm{X}_{2}, \mathrm{X}_{3}, \mathrm{X}_{4}, \mathrm{X}_{5}$ and $\mathrm{X}_{6}$. It could be seen from the table below:

Table 2. The Population of the TenthGrade Students of SMA N 1 Padangsidimpuan

\begin{tabular}{ccccc}
\hline No & Grade & Male & Female & Total \\
\hline 1 & $\mathrm{X}_{1}$ & 12 & 20 & 32 \\
2 & $\mathrm{X}_{2}$ & 13 & 18 & 31 \\
3 & $\mathrm{X}_{3}$ & 15 & 17 & 32 \\
4 & $\mathrm{X}_{4}$ & 14 & 18 & 32 \\
5 & $\mathrm{X}_{5}$ & 13 & 18 & 31 \\
6 & $\mathrm{X}_{6}$ & 20 & 7 & 27 \\
\hline
\end{tabular}




\begin{tabular}{ccccc}
\hline No & Grade & Male & Female & Total \\
\hline & Total & & 185 \\
\hline
\end{tabular}

In This Research the writer takes two classes from all classes. It consists of $X_{2}$ and $X_{5}$. The total number is 62 students from the population by cluster random sampling.

\section{Result and Discussion}

\section{Results}

\section{Reading Recount Text Ability before Taught by Problem Posing Learning}

The writer had researched SMA Negeri 1 Padangsidimpuan by contributing tests in the multiple-choice form to the tenth-grade students to know the applying of teaching methods with CIRC (Cooperative, Integrated, Reading, and Composition methods on students' ability in reading recount text. Data is important in doing the research. To describe the data, the scores of students that had been collected were calculated by applying statistical analysis which could be illustrated in the description of the data.

Based on the result of the research, the writer found the result of students in reading recount text which is different from both scores. It could be seen that students are more active when the writer uses CIRC (Cooperative, Integrated, Reading, and Composition) Method in teaching reading recounttext because this method makes the students easy to understand and open their minds. Thewriter shows the specification of calculation in the table below:

The Score of mean, median, and mode of Teaching reading recount before Taught by Problem Posing Learning Method to the tenth-grade Students of SMA Negeri 1 Padangsidimpuan.

Table 3. The score of mean, median, and mode

\begin{tabular}{lll}
\hline \multicolumn{1}{c}{ No } & \multicolumn{1}{c}{ Items } & Score \\
\hline 1 & Mean & 68 \\
2 & Median & 65 \\
3 & Mode & 65 \\
\hline
\end{tabular}

From the calculation, it is known that the mean of students' achievement in reading recount text before taught by CIRC (Cooperative, Integrated, Reading, and Composition) method is categorized as "enough". From the calculation, the position of the mean score for this variable can be drawn in the figure as follows 


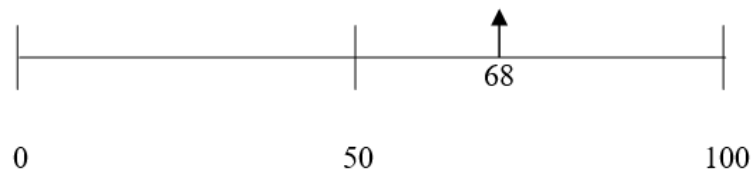

Figure 1. The position of mean score of teaching reading recount text before taught by CIRC (Cooperative, Integrated, Reading, and Composition) method to the twelfth-grade students of SMA Negeri 1 Padangsidimpuan.

Furthermore, the frequency distribution of reading recount text score before taught by reading invitation method can be presented below:

Table 4. The Frequency Distribution of Teaching reading recount text Before Taught by CIRC (Cooperative, Integrated, Reading, and Composition) method to the tenth-grade Students of SMA Negeri 1 Padangsidimpuan.

\begin{tabular}{ccccc}
\hline No & Interval & Frequency & $\begin{array}{c}\text { Cumulative } \\
\text { Frequency }\end{array}$ & Percentages (\%) \\
\hline 1 & $50-55$ & 2 & 2 & 5.71 \\
2 & $56-61$ & 1 & 3 & 2.86 \\
3 & $62-67$ & 18 & 21 & 51.43 \\
4 & $68-73$ & 8 & 29 & 22.86 \\
5 & $74-79$ & 2 & 31 & 5.71 \\
6 & $80-85$ & 4 & 35 & 11.43 \\
\hline & Total & 35 & - & \multicolumn{2}{c}{$100 \%$} \\
\hline
\end{tabular}

From the table above it is shown that the students who get score $50-55$ are 2 students or $5.71 \%$, score $56-61$ is 1 student or $2.86 \%$, score $62-67$ are 18 students or $51.43 \%$, and score $68-73$ are 8 students or $22.86 \%$, score $74-79$ are 2 or $5.71 \%$, score $80-85$ are 4 students or $11.43 \%$.

Based on the distribution above, the writer finds that most of the student's score is $62-67$, there are 18 students or $51.43 \%$. It is found the lowest score is 50 and the highest score is 85 . It can be seen in figure 2 as follows: 


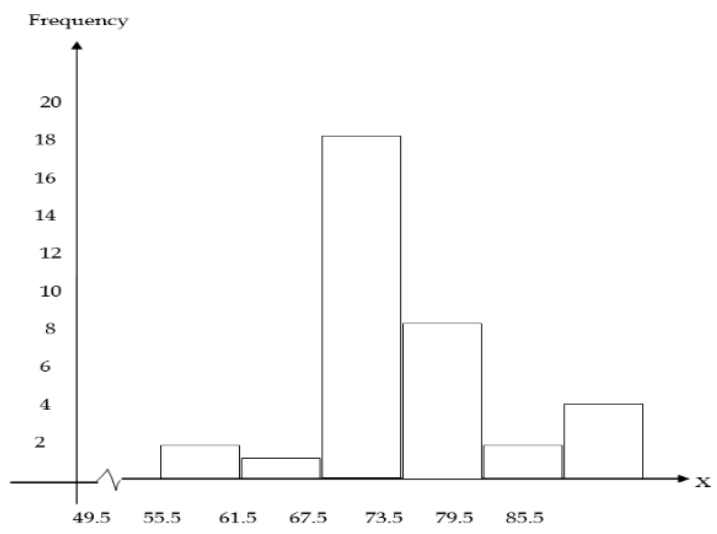

Figure 2. The histogram of teaching reading recount text before taught by the CIRC (Cooperative, Integrated, Reading, and Composition) method to the tenth-grade students of SMA Negeri 1 Padangsidimpuan.

1. Reading Recount Text Ability After Taught by CIRC (Cooperative, Integrated, Reading, and Composition) Method

After collecting the data, it is found the highest score is 95 and the lowest score is 60. The writer shows the specification of calculation in the table below:

Table 5. The score of mean, median, and mode of teaching reading recount text-ability after taught by CIRC (Cooperative, Integrated, Reading, and Composition) method to the tenth-grade students of SMA Negeri 1 Padangsidimpuan.

\begin{tabular}{ccc}
\hline No. & Data & Nilai \\
\hline 1 & Mean & 77,81 \\
2 & Median & 77,46 \\
3 & Mode & 76,37 \\
\hline
\end{tabular}

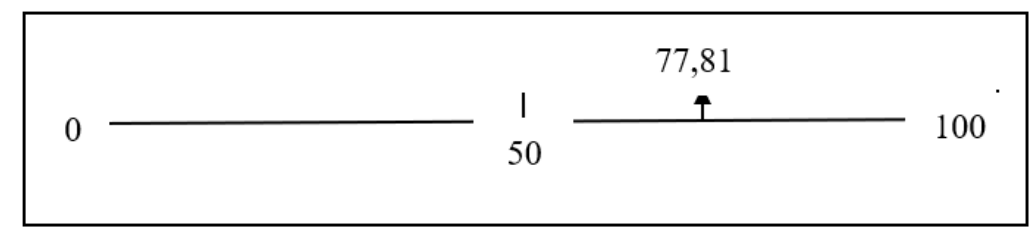

Figure 1. The Position of mean score on Students' Ability in Reading Recount Text by Using CIRC (Cooperative, Integrated, Reading, and Composition) method at the tenth-grade students of SMA Negeri 1 Padangsidimpuan 
Further, the writer served out the table of the data frequency distribution of using the CIRC (Cooperative, Integrated, Reading, and Composition) method in reading recount text of SMA Negeri 1 Padangsidimpuan 2019/2020 academic year in the table below:

Table 6.

The Frequency Distribution of Teaching Reading Recount Text by using CIRC (Cooperative, Integrated, Reading, and Composition) Method at the tenth-grade students of SMA Negeri 1 Padangsidimpuan

\begin{tabular}{|c|c|c|c|c|c|}
\hline No. & Interval & $\mathbf{x}_{\mathbf{i}}$ & $\mathbf{f}_{\mathbf{i}}$ & $\mathbf{f}_{\mathbf{i}} \mathbf{x}_{\mathbf{i}}$ & Percentages \\
\hline 1 & $60-64$ & 62 & 2 & 124 & $3,27 \%$ \\
\hline 2 & $65-69$ & 67 & 6 & 402 & $9,84 \%$ \\
\hline 3 & $70-74$ & 72 & 13 & 936 & $21,31 \%$ \\
\hline 4 & $75-79$ & 77 & 16 & 1232 & $26,24 \%$ \\
\hline 5 & $80-84$ & 82 & 11 & 902 & $18,03 \%$ \\
\hline 6 & $85-89$ & 87 & 9 & 783 & $14,75 \%$ \\
\hline 7 & $90-94$ & 92 & 4 & 368 & $6,56 \%$ \\
\hline \multicolumn{2}{|c|}{ Jumlah } & & $\mathbf{6 1}$ & $\mathbf{4 7 4 7}$ & $\mathbf{1 0 0}$ \\
\hline
\end{tabular}

Based on the table above, it could be seen that there were 5 classes and the interval was 7 of reading recount text by using Probing Prompting Learning Method at the tenthgrade students of SMA Negeri 1 Padangsidimpuan. It was found that the students who got the score $60-64$ was 3,27\%, while the students who got the score 65-69were 9,84the score 7074 were $21,31 \%$ the score $75-79$ were $26.24 \%$ the score $80-84$ were $18.03 \%$, the score $85-89$ were $14,75 \%$ and the score $90-94$ were $6,56 \%$.

To make it clear, here is the histogram:

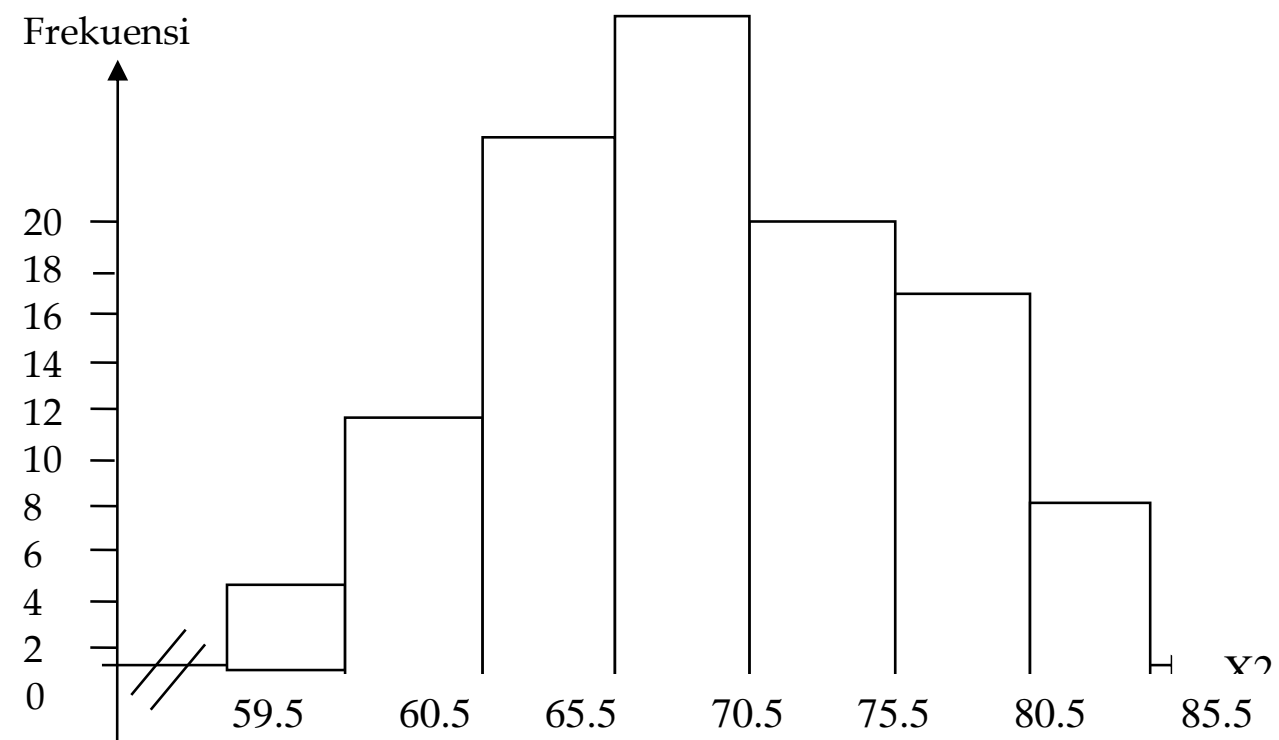




\section{Testing Hypothesis}

After collecting data, the researcher concluded that the score of data collected by using formula t-test, where the tabulation can be seen as follows:

Table 7.

Table of Correlation of Product Moment with and without the use of Circ (Cooperative, Integrated, Reading, and Composition) Methods on Students Achievement In Reading Recount Text

\begin{tabular}{|c|c|c|c|c|c|}
\hline No & $\bar{X}$ & $Y$ & $\mathbf{X}^{2}$ & $\mathbf{Y}^{2}$ & $X Y$ \\
\hline 1 & 60 & 65 & 3600 & 4225 & 3900 \\
\hline 2 & 65 & 70 & 4225 & 4900 & 4550 \\
\hline 3 & 80 & 85 & 6400 & 7225 & 6800 \\
\hline 4 & 70 & 75 & 4900 & 5625 & 5250 \\
\hline 5 & 85 & 90 & 7225 & 8100 & 7650 \\
\hline 6 & 80 & 85 & 6400 & 7225 & 6800 \\
\hline 7 & 65 & 70 & 4225 & 4900 & 4550 \\
\hline 8 & 75 & 80 & 5625 & 6400 & 6000 \\
\hline 9 & 80 & 75 & 6400 & 5625 & 6000 \\
\hline 10 & 75 & 80 & 5625 & 6400 & 6000 \\
\hline 11 & 80 & 80 & 6400 & 6400 & 6400 \\
\hline 12 & 65 & 70 & 4225 & 4900 & 4550 \\
\hline 13 & 55 & 60 & 3025 & 3600 & 3300 \\
\hline 14 & 70 & 75 & 4900 & 5625 & 5250 \\
\hline 15 & 80 & 90 & 6400 & 8100 & 7200 \\
\hline 16 & 70 & 70 & 4900 & 4900 & 4900 \\
\hline 17 & 60 & 65 & 3600 & 4225 & 3900 \\
\hline 18 & 70 & 75 & 4900 & 5625 & 5250 \\
\hline 19 & 75 & 85 & 5625 & 7225 & 6375 \\
\hline 20 & 65 & 75 & 4225 & 5625 & 4875 \\
\hline 21 & 75 & 85 & 5625 & 7225 & 6375 \\
\hline 22 & 60 & 65 & 3600 & 4225 & 3900 \\
\hline 23 & 70 & 75 & 4900 & 5625 & 5250 \\
\hline 24 & 75 & 85 & 5625 & 7225 & 6375 \\
\hline 25 & 80 & 90 & 6400 & 8100 & 7200 \\
\hline 26 & 55 & 70 & 3025 & 4900 & 3850 \\
\hline 27 & 70 & 75 & 4900 & 5625 & 5250 \\
\hline 28 & 65 & 70 & 4225 & 4900 & 4550 \\
\hline 29 & 80 & 85 & 6400 & 7225 & 6800 \\
\hline 30 & 75 & 80 & 5625 & 6400 & 6000 \\
\hline 31 & 60 & 65 & 3600 & 4225 & 3900 \\
\hline 32 & 70 & 75 & 4900 & 5625 & 5250 \\
\hline 33 & 75 & 80 & 5625 & 6400 & 6000 \\
\hline 34 & 80 & 70 & 6400 & 4900 & 5600 \\
\hline
\end{tabular}




\begin{tabular}{cccccc}
\hline No & $\mathbf{X}$ & $\mathbf{Y}$ & $\mathbf{X}^{\mathbf{2}}$ & $\mathbf{Y}^{\mathbf{2}}$ & $\mathbf{X Y}$ \\
\hline 35 & 70 & 75 & 4900 & 5625 & 5250 \\
36 & 75 & 80 & 5625 & 6400 & 6000 \\
37 & 65 & 70 & 4225 & 4900 & 4550 \\
38 & 70 & 80 & 4900 & 6400 & 5600 \\
39 & 70 & 75 & 4900 & 5625 & 5250 \\
40 & 75 & 80 & 5625 & 6400 & 6000 \\
41 & 65 & 70 & 4225 & 4900 & 4550 \\
42 & 70 & 75 & 4900 & 5625 & 5250 \\
43 & 60 & 65 & 3600 & 4225 & 3900 \\
44 & 75 & 85 & 5625 & 7225 & 6375 \\
45 & 70 & 80 & 4900 & 6400 & 5600 \\
46 & 80 & 90 & 6400 & 8100 & 7200 \\
47 & 70 & 75 & 4900 & 5625 & 5250 \\
48 & 60 & 65 & 3600 & 4225 & 3900 \\
49 & 70 & 75 & 4900 & 5625 & 5250 \\
50 & 80 & 85 & 6400 & 7225 & 6800 \\
51 & 85 & 85 & 7225 & 7225 & 7225 \\
52 & 80 & 70 & 6400 & 4900 & 5600 \\
53 & 70 & 75 & 4900 & 5625 & 5250 \\
54 & 75 & 80 & 5625 & 6400 & 6800 \\
55 & 65 & 70 & 4225 & 4900 & 7225 \\
56 & 70 & 75 & 4900 & 5625 & 5250 \\
57 & 75 & 80 & 5625 & 6400 & 6000 \\
58 & 70 & 75 & 4900 & 5625 & 5250 \\
59 & 80 & 70 & 6400 & 4900 & 5600 \\
60 & 70 & 70 & 4900 & 4900 & 4900 \\
61 & 60 & 60 & 3600 & 3600 & 3600 \\
Jumlah & 4340 & 4625 & 312000 & 354075 & 331750 \\
\hline
\end{tabular}

$\mathrm{t}_{\mathrm{o}} \quad=\frac{M_{1}-M_{2}}{S E_{M_{1}-M_{2}}}$

$\mathrm{Mx}_{1}=\frac{\sum \mathrm{x}}{\mathrm{N}}=\frac{4747}{61}=77,81$

$\mathrm{SDx}_{1}=\sqrt{\frac{\sum \mathrm{x}}{\mathrm{N}}}=\sqrt{\frac{4747}{61}}=\sqrt{77,81}=8,82$

$\mathrm{SE}_{\mathrm{MX} 1}=\frac{\mathrm{SDX}_{\mathrm{X}}}{\sqrt{\mathrm{N}-1}}=\frac{8,82}{\sqrt{60}}=\frac{8,82}{7,74}=1,13$

$\mathrm{Mx}_{2}=\frac{\sum \mathrm{X}}{\mathrm{N}}=\frac{4462}{61}=73,14$

$\mathrm{SDx}_{2}=\sqrt{\frac{\sum x}{N}}=\sqrt{\frac{4462}{61}}=\sqrt{73,14}=8,55$

$S E_{M X 2}=\frac{S D_{X}}{\sqrt{N-1}}=\frac{8,55}{\sqrt{61-1}} \frac{8,55}{\sqrt{60}}=\frac{8,55}{7,74}=1,10$

$\mathrm{SE}_{\mathrm{m} 1-\mathrm{m} 2}=\sqrt{\left(S E_{m \times 1}\right)^{2}+\left(S E_{m \times 2}\right)^{2}}$

$=\sqrt{(1,13)^{2}+(1,10)^{2}}$

$=\sqrt{1,2769+0,21}$ 


$$
\begin{aligned}
\quad=\sqrt{1,4869}= & 1,57 \\
\mathrm{t} \quad \frac{M_{1}-M_{2}}{S E_{M_{1}-M_{2}}} & \\
=\frac{77,81-73,14}{1,57} & =\frac{4,67}{1,57}=2,97 \\
& =61+61-2 \\
& =122-2 \\
\text { So, }\left(\mathrm{N}_{1}+\mathrm{N}_{2}\right)-2 & =120
\end{aligned}
$$

$5 \%$ significant level 120 was 1,98

$2,97>1,98$

$t_{o}$ was bigger than $t_{\text {table }}$

Based on the result of the calculation in testing the hypothesis, it was found that the score of the $t_{\text {test }}$ was 2,97 . The total sample was 61 , then the number of the variable of this research was 2. So, $\left(\mathrm{N}_{1}+\mathrm{N}_{2}\right)-2=61+61-2=120$. The value of $t_{\text {table }}$ at a $5 \%$ significant level of 120 was1.98. After finding the value of the calculation and $t_{t a b l e}$, both scores were compared. It was found that $t_{0}$ calculation was bigger than $t_{\text {table }}\left(t_{\text {test }}>t_{\text {table }}=2,97>1,98\right)$

\section{Discussions}

After giving the t-test to the students, the writer found the result of students in reading recount text which is different from both scores. The mean score of students in reading recount text by using CIRC was 77,81 , It could be seen that students are active when the researcher applied the CIRC method in teaching recount text because this method could help students in comprehending content and part of the text by its step and enhanced reading recount text ability.

Based on the explanation previously in the testing hypothesis, it could be seen that

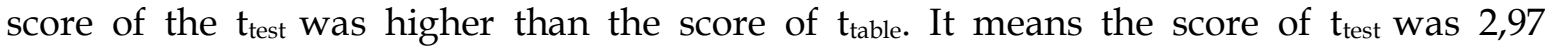
meanwhile, the score of $t_{\text {table }}$ was 1,98 at $5 \%$ significant level with degrees of freedom (df) 59 $\left(t_{\text {test }}>t_{\text {table }}=2,97>1,98\right)$. It means that the hypothesis was accepted in that the students' ability to reading recount text by using the CIRC method was better than Probing Posing learning methods at the tenth-grade students of SMA Negeri 1 Padangsidimpuan.

At the end of this writing, the writer concluded that choosing the suitable method in the teaching genre will be easier to comprehend the text and can improve students' scores to be better.

\section{Conclusion}

The result of the data description showed that the mean scores of students in reading recount text by using the CIRC (Cooperative, Integrated, Reading, and Composition) Method were 77,81 (good), the median was 77,46 (good), and the mode was 76,37 (enough). It could be said that their scores were more than their KKM value.

Based on the data analysis which was analyzed by using the $t_{\text {test }}$ formula, it was obtained that $t_{0}$ was greater than $t_{t}(10,698>1.671)$. It means that the hypothesis was accepted 
and from the statistical analysis results, it was seen that the CIRC method was a suitable method for reading recount text-ability at the tenth grade of SMA Negeri 1 Padangsidimpuan 2019/2020 academic year.

Based on the previous conclusions, the researcher stated that using a suitable method will raise students' ability in reading recount text. The teacher should use a suitable method based on students' necessity in the teaching-learning process. It is done to attract students to feel enjoyable and make them easier to understand the material, especially in reading recount text.

\section{Acknowledgment}

The writer thanks SMA Negeri 1 Padangsidimpuan especially the headmaster and English teachers of SMA Negeri 1 Padangsidimpuan which has allowed the writer to conduct the research.

\section{References}

Agustina, R. (2015). Penerapan Metode Cooperative, Integrated, Reading, and Composition (CIRC) Untuk Meningkatkan Kemampuan Mengapresiasi Cerita Rakyat Pada Siswa Kelas VIIC SMP Negeri 16 Pontianak. Jurnal Ilmiah Progressif. Vol.12 (35).

Aryani, Suprobo, Umar Samadhy, \& Nugraheti, S. (2012). Peningkatan Keterampilan Membaca Pemahaman Melalui Strategi Know-Want-Learned (KWL) Pada Siswa Kelas IVA SDN Sekaran 01 Semarang. Joyful Learning Journal. Volume 1 (1).

Hafizah, H., Wahab, D. A., Hussain, A., Samad, S. A., Mohamed, A., Azhari, C. H., \& Tahir, N. M. (2010). Kajian kes ke atas kesan kaedah pembelajaran koperatif teknik'Jigsaw'dalam kursus isyarat dan sistem. ASEAN Journal of Teaching and Learning in Higher Education, 2(1), 12-21.

Iskandarwassid \& Dadang, S. (2013). Strategi Pembelajaran Bahasa. Bandung: PT Remaja Rosdakarya.

Kamisah, O., Wahidin, \& Subahan. M. M. (2013). Concept mapping in chemistry lessons: Tools for inculcating thinking skills in chemistry learning. Journal of Baltic Science Education, 12(5), 666-681.

Kendal, S. (2015). How to Write a Research Paper. UK: Bookbon.

Maruf, N., \& Anjely, M. R. (2020). Utilizing Cooperative Integrated Reading and Composition (CIRC) with Mobile Learning to Enhance Students' Reading Comprehension. British, Jurnal Bahasa dan Sastra Inggris, 9(2), 10-19.

Ridwanuddin, D. (2015). Bahasa Indonesia. Jakarta: UIN Press. 2015.

Siregar, S. (2014). Metode Penelitian Kuantitatif. Jakarta: Kencana Prenada Group. 
Souzanzan, R., \& Zamaniyan, M. (2014). The Relationship Between the Location Of The Topic Sentence And The Comprehension Of A Passage By Iranian Advanced EFL Learners. Modern Journal of Language Teaching Methods, 4(2), 237.

Suarsana, I., Lestari, I. A. P. D., \& Mertasari, N. M. S. (2019). The Effect of Online Problem Posing on Students' Problem-Solving Ability in Mathematics. International Journal of Instruction, 12(1), 809-820.

Sugiyono. (2013). Metode Penelitian Kuantitatif, Kualitatif, dan RED. Bandung: CV. Alfabeta.

Ting, S. H., Campbell, Y. M., Law, L., \& Poh, H. H. (2013). Explanations without a purpose? Genre-based instruction and academic writing. Journal of Academic Language and Learning, 7(1), A26-A39.

Yaumi, M. (2013). Prinsip-Prinsip Desain Pembelajaran. Jakarta: Kencana.

Yigit, E. A. (2015). Exploring the relationship between cognitive structure outcomes and test achievements of pre-service science teachers on chemical bonding via flow mapping. Journal of Baltic Science Education, 14(4), 524-534. 